Rev. Krzysztof Rudziński

Nice, France

\title{
Responsibility for Sin in Ezekiel 18:21-28
}

This article discusses the problem of responsibility in Ezekiel 18:21-28. In the first part of the article, the author presents the principle of collective responsibility in ancient Israel. The second part shows the teaching of the prophet Ezekiel, who contrasts the former universally applicable principle of collective responsibility with his completely novel concept of individual responsibility. According to this new principle, everyone is personally responsible for his own behavior. A sinner can save his life by converting and entering on the path of a real spiritual life.

For centuries the Catholic Church has interpreted Ezekiel's encouragement to convert as an indirect invitation for the modern listener to be open to Christ.

Key words: Ezekiel, collective responsibility, individual responsibility, sinful man, sin, conversion.

\section{Introduction}

Up until the $6^{\text {th }}$ century BC (i.e., up to the time of the prophet Ezekiel), Israel commonly accepted the principle of collective responsibility for sin. When Babylonians attacked Judea, part of the nation of Israel was exiled (597 BC) and the city of Jerusalem completely collapsed (586 BC). Unable to come to terms with this predicament, the fractured society bitterly asked: Why are we suffering? Is this harsh experience that has fallen upon us a punishment for the sins of our fathers? In contrast to this view, the prophet Ezekiel presents a completely new concept of individual responsibility for one's own conduct. A sinner can save his life by repenting and leading a truly spiritual life.

This article will first present the principle of collective responsibility that was commonly accepted in Israel until the time of the prophet Ezekiel. Then it will explain the prophet Ezekiel's novel solution to this problem. 


\section{The principle of the collective responsibility in the ancient Israel}

Before the Babylonian captivity, the Jewish people widely accepted the principle of collective or "inherited" responsibility. This tradition was due to the way in which the Jewish people understood what it meant to keep the covenant in the Old Testament. God had entered into a covenant with Noah and had called Abraham (cf. Gen 12:2), and in both instances God's intervention affected the entire family, social group, city, and nation. "God said to Noah and his sons with him: See, I am now establishing my covenant with you and with your descendants after you" (Gen 9:9). This passage serves as the basis for the Old Testament's understanding of the principle of responsibility that all members of the community must follow without exception.

Biblical Theology

Social connections among inhabitants of a particular city were also understood in this way (cf. 1Sam 5:9-10). This understanding of the connection between individuals in the community applied not only to blessings but also to sin and, thus, to allegedly "inherited" faults. This theory, however, was strongly called into question at the time of the fall of Jerusalem. ${ }^{1}$

The collective way of thinking about corporate responsibility for a collective fault is expressed in the proverb: "Parents eat sour grapes, but the children's teeth are set on edge" (Ez 18:2; cf. Jer 31:29). While this proverb is not part of the passage from Ezekiel being discussed, it is related to Ezekiel 18:25, which conveys the Jewish people's lack of hope and critical attitude toward God's justice-what W. Zimmerli describes as "nihilistic cynicism." The idea that those in exile were suffering because of the sins of their fathers was constantly repeated among the Jewish people, which Ezekiel 18:2 confirms. When understood more broadly, the expression "parents" in Ezekiel 18:2 means the preceding generation(s). In a more restricted sense, this word also signifies a grandfather or father (cf. Gn 28:13); someone who came up with a certain a profession (cf. Jer 35:6); or a well-respected individual such as a prophet, teacher, or priest (cf. 1Sam 24:12; 2Kings 2:12; Jg 17:10). "Parents" can also mean a guardian who has become like a father to the people entrusted to him (cf. Is 22:21); an advisor, a landlord, or an administrator (cf. Gn. 45:8); and someone who begets the rain and

$1 \quad$ Cf. R. Rumianek, Z rozważan nad Starym i Nowym Testamentem, Warsaw 2001, pg. 8; J. M. Assurmendi, “Le prophète Ezéchiel,” Cahiers Evangile 38(1981), pg. 39.

$2 \quad$ Cf. W.Zimmerli, "Le message du prophète Ezéchiel," Cahiers Bibliques 11(1972), pg. 23 
dew (cf. Jb 38:28). In Israel, a father is the head of the family who-as God's representative-makes decisions regarding his children's future. The father was entrusted with caring for his family and the tasks that this responsibility involved. Mothers also had the same privilege, but their role was considered secondary (cf. Ex 20:12). In Jewish culture, anyone who disrespected his father or mother was subject to punishment (and even death), since both parents deserved to be honored and praised (cf. Ex. 21:15). ${ }^{3}$ By using the expression "the children's teeth are set on the edge," Ezekiel seeks to tell the exiles who believe they are being punished for the sins of their fathers that they are wrong. The prophet asks the people why they follow this custom. For they know, after all, that God's Law is based on an entirely different set of precepts and teachings. Although the principle of being responsible for the acts of others was commonly known even outside of Israel, its origins are ambiguous. Some exegetes think that this principle comes from the wisdom of an age-old tradition, while others assert that it arose out of the religious and moral crisis that took place at the end of the Kingdom of Judah. The majority of scholars tend to claim that the proverb reflects a general spiritual and ethical corruption that the nation of Israel did not want to acknowledge. It is easier blame current disasters on one's ancestors because this renders any personal attempt to make moral changes within oneself pointless. This widespread way of thinking is common in the books of the Old Testament, where collective responsibility is a fundamental theme. By following the negative traditions passed down from their ancestors, the Israelites limit their awareness of their national identity exclusively to natural bonds that can be traced back to the pre-patriarchal period. ${ }^{4}$

A person's "teeth are set on edge" as a result of consuming unripe berries or grapes. When the prophet Ezekiel uses this expression, he does not say anything about the Palestinian custom of cleaning teeth because he is more concerned with turning the listener's attention more acutely to the concept of purification from sin. When commenting on this expression, some exegetes point out the popular belief that unripe grapes damaged teeth more quickly. Figuratively speaking, this expression conveys how sin brings about lasting effects, so much so

$3 \quad$ Cf. R. Rumianek, "Problem odpowiedzialności według Ez 18,2," in: Miłość jest $z$ Boga. Wokót zagadnień biblijno-moralnych. Studium ofiarowane ks. prof. dr. hab. Janowi Łachowi, ed. M. Wojciechowski, Warsaw 1997, pg. 359n. The author discusses who "fathers" are and what "teeth are set on edge" means.

$4 \quad$ Cf. A.S. Jasiński, Księga Proroka Ezechiela. Nowy Komentarz. Ez 16-20, vol. 5, Opole 2018, pg. 275n.280n; R. Rumianek, Orędzie Księgi Ezechiela, Warsaw 1999, pg. 114. 
Biblical Theology

that "teeth [that] are set on edge" (i.e., individuals) morally decay more quickly. ${ }^{5}$ This proverb, which mocks God's justice by implying that $\mathrm{He}$ would make the "sons of Israel" suffer for the sins of their fathers, was undoubtedly familiar to the exiled people. Ezekiel refutes this expression by reminding the Israelites about God's revelation concerning them as well as the fact that they are God's Chosen People, which, however, does not necessarily ensure that they will have a happy life with God. The prophet wants to indicate that every individual person needs to participate in the life of God: "[S]ince they turned away from all the sins they committed, they shall live; they shall not die" (Ez 18:28). In this way, examples from the past and the present can serve as a lesson to the Israelites and may help them in a particular way to achieve unity between the different generations. However, in this continuity from one generation to another, it is important that children do not imitate their fathers' bad examples. ${ }^{6}$

\section{Ezekiel's New Solutions}

Ezekiel 18:21-28 provides a response to the question: "Whose is at fault?" by clearly formulating the principle of individual responsibility for one's own evil and good conduct. Whether noble or reprehensible, a person's actions cannot be passed down in any way. Ezekiel's clear understanding of this issue could have been influenced by the theological tradition of the time. This tradition and the prophet Ezekiel's mission are interconnected. As a priest who officiated in the Temple, Ezekiel uses legal languages and expressions that contain elements of casuistry that was characteristic of priestly tradition in his description of his vision (cf. Lv. 17:3, 8, 11, and 13). Ezekiel uses the same expressions that priests who served in the Temple used: if, when, so, then (verses 21-28) ${ }^{7}$. Despite the fact he presents his insights in a form that clearly resembles that used by priests in their teaching faculty while

$5 \quad$ Cf. W.Zimmerli, Ezechiel 1-24 (Biblischer Kommentar Altes Testament, vol. 13/1), Vluyn 1979², pg. 401n; R. Rumianek, "Problem odpowiedzialności,” pg. 364.

$6 \quad$ Cf. R. Rumianek, "Problem odpowiedzialności,” p. 364; A. Fournier-Bidoz, "Le livre Ezéchiel," in: J. M. Assurmendi, J. Ferry, A. Fournier-Bidoz, Les livres des Prophètes. Ezéchiel, Daniel, les douze prophètes, vol. 2, Paris 1999, pg. 54n; G. Witaszek, Myśl społeczna proroków, Lublin 1998, pg. 179.190n.

7 See: J. Weingreen, Hébreu Biblique. Méthode élémentaire. Nouvelle édition revue et corrigée, trans. P. Hebert, J. Morgain, Paris 1984, pg. 34n. (Preposition: Đ, Đ, ); J. Strong, Hebrajsko-polski i aramejsko-polski stownik Stronga z lokalizacja stów hebrajskich i aramejskich oraz kodami Baumgartnera (Prymasowska Seria Biblijna 45) (H3588), trans. A. Czwojdrak, Warsaw 2017, pg. 500. (Preposition, particle: 
making his point, these insights take on a completely different and "prophetic" meaning in Ezekiel's case. His message far surpasses the model of simple religious instruction. His message includes insights on morality and ethics, which the teachings of the Temple priests did not (cf. Ez 14, 18, 33) ${ }^{8}$.

Since he recognizes that God's action plays a very important role in a person's life, Ezekiel uses chiasmus-a rhetorical or literary figure that inverts words, concepts, or grammatical constructions when they are repeated-when conducting his analysis.

A. (vv. 21-23): the wicked man who converts will not be charged for the sins he previously committed.

B. (v. 24): the righteous man who follows in the footsteps of a sinner will be punished.

C. (v. 25): God's justice is unboundedly greater than that of man.

B'. (v. 26): the righteous man who strays will be punished.

A'. (v. 27-28): the wicked man who turns away from his transgressions will be forgiven. ${ }^{9}$

Verses 21-23 and 24-26 contain Ezekiel's response to the exiled Israelites' assertions that they are being punished for the sins of their ancestors. These verses contain a riposte to the well-known and widely held opinion regarding punishment for one's forefathers' transgressions (cf. Ez 18:2; Jer 31:29) and prove that this belief is not true (cf. Ex 20:5; Deut 5:9; Jer 31:29). When one follows God's commandments, God rewards such a person for his virtuous acts regardless of the sins that his fathers committed (cf. Ez 18:5-9; Ex 22:25-26; Lev 25:35-37). If he

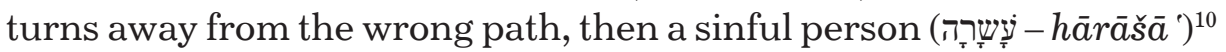
will live; however, when a righteous man falls into sin and persists in

$8 \quad$ See: J.M.Assurmendi, “Le prophète Ezéchiel,”pg. 39n; M. Dubreucq, "Ezéchiel. A qui la faute? La responsabilité personnelle en Ez 18," Les Dossiers de la Bible 63(1996), pg. 29.

$9 \quad$ Cf. J. M. Assurmendi, “Le prophète Ezéchiel,” pg. 39n; M. Dubreucq, "Ezéchiel. A qui la faute? La responsabilité personnelle en Ez 18," Les Dossiers de la Bible 63(1996), pg. 29.

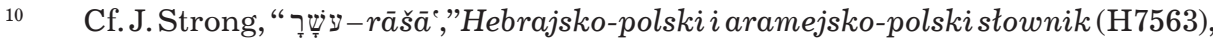
pg. 1028; J. Weingreen, Hébreu Biblique. Méthode élémentaire, pg.32n. The definite

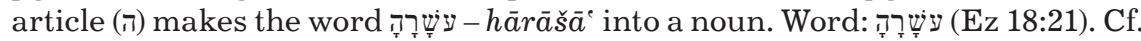
Księga Ezechiela, pg. 1013 [Biblia Tysiąclecia]; Fr. R. Rumianek, Księga Ezechiela. Ttumaczenie i komentarz, Warsaw 2009, pg. 128; Fr. J. Homerski, Księga Ezechiela.Ttumaczenie, wstęp i komentarz, Lublin 1998,pg. 75 [Biblia Lubelska]; Fr. A. S. Jasiński, Księga Proroka Ezechiela. Ez 16-20, pg. 326; I. Cylkow, Księga Ezechiela. Ttumaczenie I. Cylkow, Cracow 2010 (Reprinted edition: Księga Ezechiela, tłomaczyt i podtug najlepszych źródeł objaśnit Dr. J. Cylkow, Issued by the translator of the J. Fischer printing house in Cracow, 1900), pg. 93). 
his sin, he will die (v. 21-23). In this case, a simple appeal to convert is insufficient. Ezekiel describes conversion in a specific way in Chapter 18. He mentions three consecutive generations: "the virtuous man" (cf. Ez 18:5-9), "the unvirtuous man"-his violent son (cf. Ez 18:10-13, 18), and "the virtuous man"- the grandson (Ez 18:14-17). Each one of them receives payment for the way he lived. The description of a virtuous person recalls the liturgical practice of "entrance into the Temple." The man who fulfilled the requirements of the Law was pronounced righteous at the Temple gate. Therefore, he was permitted to enter the House of God, where he received the promise of life and God's blessing. These singular and original examples illustrate of what true conversion consists. Referring to a liturgical ritual, especially at the time when the Temple had already been destroyed and a worship took place on "unclean" land, the prophet calls the exiles to the return spiritually to

Biblical Theology the Temple gate and asks them to come to know the "promise of life" had once been preached there. ${ }^{11}$ Ezekiel 18:21-23 takes a person's past into account and not the bonds of blood. He does, however, extend the rule of punishment to apply to the different stages of the life of a sinful person who converts and subsequently leads a virtuous life and who can, therefore, be certain that his previous iniquities (פֶ๊ - peša ' $)^{12}$ will not be remembered (v. 22). Righteousness is not the habitual disposition of someone who has free will. In other words, at every moment every person has the freedom to choose between good and evil. For this reason, even a virtuous person can go astray and turn away from his virtuous life. The moment a virtuous man commits iniquity he will die because of his sins, since none of his previous acts will have an effect on his fate (v. 24). Unlike the wicked person who discredits the Lord's justice, God truly distributes His rewards and punishments according to very clear principles. ${ }^{13}$ Unfortunately, the voice of the unrighteous who reject every form of hope is much stronger. They openly oppose God (vv. 25 and 29) and accuse Him of being unjust. Those who fear God also despair and reject any kind of prospect of

11 Cf. W. Zimmerli, "Le message du prophète Ezéchiel,” pg. 24; A. Fourier-Bidoz, "Le livre d'Ezéchiel," pg. 52; See also: J. Homerski, "Komentarz do Księgi Ezechiela," in: Pismo święte Starego i Nowego Testamentu w przekładzie z języków oryginalnych ze wstęami i komentarzami. Ksiegi prorockie, ed. M. Peter, M. Wolniewicz, vol. 3, Poznan $1992^{3}$, pg. 421n [Biblia Poznańska].

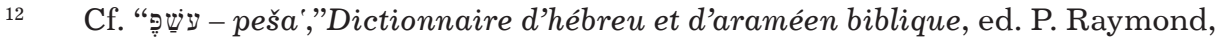
Paris-Villiers-le Bel, 1991, 2017, pg. 311; Dictionnaire Hébreu-Français, ed. N.P. Sander, I. Trenel, présentation de G. Weil, Genève 2005 (Paris, 1859), pg. 599.

13 Cf. R. Wilson, "Ezekiel," in Harper's Bible Commentary, ed. J. L. Mays, San Francisco 1988, pg. 676. 
hope (cf. Ez 33:10). ${ }^{14}$ By shifting the focus away from the principle of collective responsibility to individual responsibility, Ezekiel simultaneously provides responses to difficult questions that the exiled Israelites frequently posed to themselves. Perceiving themselves as members of the community, the Israelites did not individually consider themselves responsible for their own evil conduct. Instead, each individual held himself accountable only for his own acts, for which God would judge him. Every individual is personally responsible for his own transgressions as well as his own merits, neither of which, particularly transgressions, passed down from one's ancestors. God does not act toward us according to the merits and mistakes of our ancestors. ${ }^{15} \mathrm{~A}$ sinner can save his life by beginning a true spiritual life. Everyone, even the evildoer, can experience a change of heart during his life, if only he turns away from his sin. This truth is repeatedly confirmed in vv. 21-24, 26-28, and 32. These verses contain Ezekiel's heartfelt encouragement that a sinful person can begin a new life, which he describes in terms of a "new heart" and a "new spirit" (cf. Ez 18: 31). This new life, which is above all spiritual, should be proven by the sincere will to convert. Turning away from sin is a condition for reconciliation with God. By receiving the grace of reconciliation, a sinner enters into a relationship with God, who desires not his death but happiness and the joy of life:16 "Turn back and live!" (Ez 18:32).

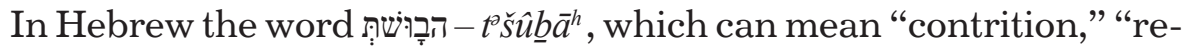
morse," "change," as well as "return," "reversion," "turning around," and "about-face," 17 conveys the reality of conversion. Biblically speaking, the word can mean a return to God (cf. Deut 4:30). This word is a very important in Judaism because repentance and contrition precede God's forgiveness, the acceptance of which is one of the greatest gifts

14 Cf. W. Zimmerli, "Le message du prophète Ezéchiel,” pg. 23; A. S. Jasiński, Ksiega Proroka Ezechiela. Ez 16-20, pgs. 328, 330; R. Rumianek, "Problem odpowiedzialności,” pg. 364.

15 Cf.. R. Rumianek, "Problem odpowiedzialności,” pg. 360; J. M. Asurmendi, "Le prophète Ezéchiel," pg. 40n.

16 Cf. J. Homerski, Księga Ezechiela, pg. 76n [Biblia Lubelska]; Ibid, "Wstęp do Księgi Ezechiela," in: Pismo święte Starego i Nowego Testamentu w przekładzie z języków oryginalnych ze wstępami i komentarzami. Księgi prorockie, ed. M. Peter, M. Wolniewicz, vol. 3, Poznan 1992², pg. 389 [Biblia Poznańska]; Ibid, "Komentarz do Księgi Ezechiela,” pg. 423 [Biblia Poznańska]; A. S. Jasiński, Księga Proroka Ezechiela. Ez 16-20, pg. 327.

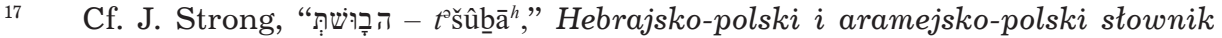
(H8666), pg. 1177.(f); B. Davidson, The Analytical Hebrew, 704. בוּש -šub: "to turn, turn back, return." 
Biblical Theology

that God gives a person. Turning back to God and turning away from the path of evil, which the prophets so often preached, indicates the path marked out by God, which should become a way and a rule of life. Rejecting this path is always bad decision (cf. Is 44:22; Mic 3:7; Ez $33: 11) .{ }^{18}$ Conversion is, therefore, a stage in the life of a given person. Ezekiel points out two paths: either the sinner can convert or the righteous man can become depraved. These two paths are not even because a cry to God from the heart, which finds its source in God who desires that the lost person make a willing change in behavior so that he might live (v. 23), describes a sinner who converts and subsequently escapes death. This choice also entails a specific decision and effort to turn away from sin. In contrast, the second path is that of the one who claims to be righteous but has committed sin and persists in it: "None of the justice [he] did shall be remembered" (v. 24). In this case, the good acts of a righteous person who has turned away from God will no longer be counted because only the present moment and all of his good decisions made in the present will determine his lot. Everyone will be judged at the appointed time, meaning in the here and now. What will count, therefore, are a person's actual and present deeds. When discussing Ezekiel 18:24, Fr. A. S. Jasiński states that this statement is a warning directed to all those who claim that they will be judged favorably for their previous good deeds. This verse is also an assurance that the path to conversion and grace is still open to the unrighteous. The one who converts will save his life, but the one who gives into depravity will die. Could the way not be any easier? Or, perhaps it is too easy! $!^{19}$ At this point it is worth considering how the tone of Ezekiel's pronouncement shifts from to second-person plural in v. 25. This characteristic mixing of singular and plural persons indicates that the Israelite community was perceived as a physical unit. This perception could also apply to a city or nation. Frequent repetitions that occur in the remaining verses of Chapter 18 also demonstrate what kind of spirit prevailed among the exiles. ${ }^{20}$ The complaint that is repeated in vv. 25 and 29 once again brings to light that the Israelites did not know that each individual's past had no effect whatsoever on God's judgment. A person's past neither gets in the way (v. 22) nor improves (v. 24) a

$18 \quad$ Cf. "Repentir," in Dictionnaire encyclopédique du Judaïsme, ed. G. Wigoder, comp. S. A. Goldberg et al., Paris 1993, pg. 960.

19 Cf. J. M. Asurmendi, "Le prophète Ezéchiel,” pg. 40n; A. Fourier-Bidoz, "Le livre d'Ezéchiel,” pg. 54; A.S. Jasiński, Księga Proroka Ezechiela. Ez 16-20, pg. $330 \mathrm{n}$

20 Cf. J. M. Assurmendi, “Le prophète Ezéchiel,” pg. 39; M. Dubreucq, "Ezéchiel. A qui la faute?," pg. 29. 
person's fate. Ironically, some exiled Israelites turned the argument on God and claimed that He Himself is accountable for a person's behavior because He offers life to the sinner who converts and accuses the righteous person who is unfaithful to Him. It appears that the latter were engaged in this debate because they accused the prophet Ezekiel of preaching precepts that were analyzed incorrectly and, therefore, erroneous. Ezekiel rejects this position and points out that their present (and not their past) sin and all of its consequences are the cause of their present suffering. ${ }^{21}$ The Bible frequently discusses the problem of sin. Yet, it is not possible to designate one precise and specific term to describe this very difficult reality. Formulas that describe sin most commonly reflect the ties between people. While they illustrate these situations and point out men's injustice, rebellion, wickedness, and failures in keeping law or voluntary mistakes, all of the prophets fully state that throughout history sin and its scale have been a condition that distances both the nation and a particular person from God. In addition, violence and injustice that result in harming one's neighbor has always been considered a sin against God Himself. When we consider this phenomenon in light of the covenant, the prospect of violating this covenant comes to the fore. Guilt and punishment for sin are one and the same because they emphasize the truth that evil acts always bring about evil effects that affect every person. ${ }^{22}$ Although the principle of collective responsibility has not been abolished, it is not to be understood or perceived as a blind tool of punishment in the hands of God. A person's future depends only and exclusively on his conduct. In this text, the inspired author offers a general norm for the moral life: "Justice belongs to the just, and wickedness to the wicked" (v. 20b). ${ }^{23}$ Fr. A. S. Jasiński stresses that these concepts were almost completely unknown during the time when Ezekiel lived. Ezekiel, therefore, is the one who was responsible for introducing a new groundwork for

$21 \quad$ Cf. A. Fourier-Bidoz, "Le livre d'Ezéchiel,” pg. 54; M. Dubreucq, "Ezéchiel. A qui la faute?," pg. 29; R. Rumianek, Księga Ezechiela, pg. 152; A. S. Jasiński, Ksiegga Proroka Ezechiela. Ez 16-20, pg. 280.331n. In his interpretation of this proverb, Fr. Jasiński refers the reader to the proverb contained in Ez 16,44c: "Like mother, like daughter" and states: "Nobody could oppose such 'wisdom.' They accepted this as a legacy from their ancestors and-as such—could not be up for discussion or modification."

22 Cf. R. Rumianek, Orędzie Księgi Ezechiela, pg. 105; H. Langkammer, Stownik biblijny, Katowice 1989, pg. 65; 50 mots de la Bible, ed. P. Gruson, CE 123(2003), pg. 41.

23 Cf. R. Rumianek, Księga Ezechiela, pg. 128. "Ez 20b,” in J. Homerski, Księga Ezechiela, pg. 75 [Biblia Lubelska]. 
the moral evaluation of human acts that will ultimately be expressed in the New Testament ${ }^{24}$.

Verses 26-28 repeat the previous statements and emphasize the consequences of bad or good behavior-namely: punishment for those who commit offenses and iniquities committed, or a reward for sinners who make positive changes in their lives. While referring to v. 22, v. 28 repeats the idea of assessing the sins of one's ancestors, which is mentioned in v. 14. This opinion influences whether the offender will make a mature decision to abandon his sinful behavior and embark on the path of doing good. ${ }^{25}$

\section{The Essence of Ezekiel's Message}

Ezekiel 18:21-28 contains the prophet's response to those living in

Biblical Theology exile who openly offend God by accusing Him of being unjust toward them. Living in a state of hopelessness, the Chosen Nation had rejected all proclamations of a better future (cf. Ez 33:10). The community of Jewish captives unceasingly questioned: "Is it right that God makes sons pay for the transgressions of their fathers without considering the merits of the righteous? How can we get out of this vicious cycle and its effects? Is it possible to begin a completely new life? (cf. Deut 5:9-10). Exile seemed to justify the Israelites belief that they were being punished for the sins of their fathers. For this reason, Ezekiel-like other prophets before him-begins to show the people God's mercy, which pervades human history and opens it up to the future. ${ }^{26}$ In Ezekiel 18:21-28, the prophet Ezekiel crushes the Israelites' belief that exile is a punishment for the sins of their ancestors. On a broader level, the placement of Chapter 18 within the Book of Ezekiel speaks to this fact. For, this chapter clearly interrupts the continuity of the Chapters 16-20. Chapter 16 presents a new vision of the history of Israel's sin and the promises that God made to the Israelites. ${ }^{27}$ Chapter 17 is an allegory

$24 \quad$ Cf. A.S. Jasiński, Księga Proroka Ezechiela. Ez 16-20, pg. 317. Ez 20b. Fr. Jasiński indicates that this verse is referring to the later formulations in the New Testament, where references to the topic of righteousness can be found in Jesus' teaching (cf. Mt 5:20).

Ibid, pg. 333n.

Cf. W. Zimmerli, "Le message du prophète Ezéchiel," pg. 23; por. A. FourierBidoz, "Le livre d'Ezékiel,” pg. 50n.

Cf. A. Fourier-Bidoz, "Le livre d'Ezéchiel,” pgs. 44-47; Księga Ezechiela, 1010 [Biblia Tysiąclecia]. Reference to Ez 16:1-63: "The Prophets often portray the chosen nation as God's Bride, who has been unfaithful to her Bridgroom by worshipping forgein gods. The Bridegroom, however, forgives his Bride for 
known as a "riddle" as well as a "parable" that, on the one hand, shows the downfall of the king of Jerusalem and his officials (vv. 11-22) and, on the other hand, foretells a new reality (vv. 21-22). ${ }^{28}$ Chapter 19 is a lamentation over the kings of Judah, and Chapter 20 presents a critical perspective of the relationship between the Chosen People and God. ${ }^{29}$ In the middle of these chapters, Chapter 18 appears and announces the importance of living a righteous life. In other words, Chapter 18 is placed between chapters that contain images that describe Israel's unfaithfulness. The story of Israel's infidelity does not depend on a twist of fate that could potentially frustrate individuals. For, this story takes on the form of a debate, during which it is enough to simply respond to the charges and support one's responses with evidence. The pericope Ezekiel 18 contains four accusations against God (vv. 2, 19, $25,29)$ that serve as the starting point of this polemic. It is completely objective and unobstructed by the vivid tone of speech, which, beginning at v. 23, leads to the presentation of the purpose of the parable (i.e., the promise of life offered to those who will observe God's Law). ${ }^{30}$

In Ezekiel 18, before the catastrophe has occurred, the inspired author meditates upon the values according to which the members of the Chosen People live. He proceeds to announce the concept that the punishment that was to befall the nation could be reversed and revoked. He also preaches to the people a new teaching concerning individual responsibility (cf. Deut 24:16; 2Kings 14:5-6) that abrogates the old concept of collective responsibility, according to which sons are responsible for the sins of their fathers. Ezekiel's novel teaching on individual responsibility as well as the prophets' (particularly Jeremiah) exemplary lives reveal the value of each person as

her infidelity and resolving to enter into a new covenant with her, which is accomplished in the New Testament."

Cf. J. Homerski, Księga Ezechiela, pgs. 69-73 [Biblia Lubelska]. Ez 17:1-24: Przypowieść o orłach; op. cit., pg. 72n: "By allegorizing the parable (vv. 22-24), the prophet foretells a new reality. [Ezekiel's] references to the 'highest mountain' (cf. Is 2:2) and the 'cedars' that resemble the cosmic life (cf. Dan 4:7-9; Mt 13:32) call to mind the messianic times of the Kingdom of God's (cf. Is 11:11; 53:12; Ps 89:4-5, 35-38)."

Cf.. J. Homerski, “Komentarz do Księgi Ezechiela,” p. 77-86 [Biblia Lubelska]. "Lamentation (Ez 19:1-14). The allegorical parable, which takes the form of a lamentation for the kings of Judah, in a certain sense completes the thoughts presented in the parable about eagles (17:1-24). [...] "A lion among lions" means the Kingdom of Judah, and the "young lion" (vv. 3-4) likely suggests King Joachaz (609), who was imprisoned by the Farao Neko II (609-593) and taken to Egypt (cf. 2K 23:31-34)". 
an individual. Ezekiel's ministrations bear the hallmark of pastoral action. He preaches that the people must begin to live as new persons and make for themselves "a new heart" and "a new spirit" from this moment onward (cf. Ez 18:31). ${ }^{31}$

\section{Conclusion}

Ezekiel 18:21-28 conveys a deep tension, particularly with regard to the question of individual responsibility, and calls the listener to choose the path of life. In this passage, the prophet Ezekiel tries to transcend traditional theological frameworks by emphasizing that an individual's behavior (and not what occurs in society) determines life or death. While it might appear that the prophet is speaking about his own individuality, his teachings speak more about his concern for and responsibility

Biblical Theology toward the people who God has entrusted to him. In other words, God's messenger, who comes to promise new life to the exiled Jewish nation and the return of God's presence to the Temple, is expressing his concern for the one person his words will encourage to not look behind, but to set out on the path to renewal. ${ }^{32}$ As for the nation, what is important is that it does not return to the hardness of heart of its ancestors. Like the Jewish people, we need to look towards the future and renew how we live. Everything depends upon the decisions of a concrete individual who God endows with the freedom to choose. ${ }^{33}$ As the "prophet-guardian," Ezekiel speaks to his listeners in the name of God about their need for conversion. He invites them to change their ways and to transform their hearts. Centuries later, the Catholic Church simply adds that Ezekiel's encouragement to convert is an indirect invitation for contemporary listeners to open their hearts to Christ. ${ }^{34}$

$\overline{31}$ Por. A. Gelin, "Les livres prophétiques postérieurs," in: Introduction à la Bible. Introduction générale, Ancien Testament, ed. A. Robert, A. Feuillet, vol. 1, Tournai $1959^{2}$, pg. $546 \mathrm{n}$.

32 Cf. W. Zimmerli, "Le message du prophète Ezéchiel," pg. 24n; M. Dubreucq, "A qui la faute?," p. 29; Ch. T.Bedd, "Księga Ezechiela," in: Stownik Wiedzy Biblijnej (Prymasowska Seria Biblijna 5), ed. B.M. Metzger, M. D. Coogan, consultant for the Polish edition W. Chrostowski, trans. P. Pachciarek, B. Olszewska, Warsaw 1996, pg. 341.

34 Cf. A. Rose, "Introductions aux lectures de l'année liturgique," in: Missel de la Semaine présenté par P. Jounel. Texte liturgique officiel, Paris 1g973, pg. 174. 


\section{Bibliography:}

1. Asurmendi, J. M. "Le prophète Ezéchiel," Cahiers Evangile 38(1981).

2. Bedd, Ch. T. "Księga Ezechiela." In Stownik Wiedzy Biblijnej (Prymasowska Seria Biblijna 5). Edited by B. M. Metzger, M. D. Coogan. Consultant for the Polish edition W. Chrostowski. Translated by P. Pachciarek, B. Olszewska, Warsaw 1996, pgs. 339-341.

3. Cylkow, I. Ksiegga Ezechiela. Ttumaczenie I. Cylkow, Cracow 2010 (Reprinted edition of: Księga Ezechiela, tłomaczyt i podtug najlepszych źódet objaśnit Dr. J. Cylkow. Issued by the translator of the J. Fischer printing house in Cracow, Cracow1900).

4. Dictionnaire d'hébreu et d'araméen biblique. Edited by P. Raymond, ParisVilliers-le Bel, 1991.

5. Dictionnaire Hébreu-Français. Edited by N. P. Sander, I. Trenel. A presentation by G. Weil, Genève 2005 (réimp. de l'édition de Paris, 1859).

6. Dubreucq, M. "Ezéchiel. A qui la faute? La responsabilité personnelle en Ez 18," Les Dossiers de la Bible 63(1996).

7. Fournier-Bidoz, A. "Le livre Ezéchiel." In J. M. Assurmendi, J. Ferry, A. Fournier-Bidoz, Les livres des Prophètes. Ezéchiel, Daniel, les douze prophètes, Vol. 2, Paris 1999, pgs.17-84.

8. Gelin, A. "Les livres prophétiques postérieurs." In Introduction à la Bible. Introduction générale, Ancien Testament, red. A. Robert, A. Feuillet, Vol. 1, Tournai $1959^{2}$, pgs. 465-582.

9. Homerski, J. Księga Ezechiela. Ttumaczenie, wstęp i komentarz, Lublin 1998, p. 10-12 [Biblia Lubelska].

10. Homerski, J. "Komentarz do Księgi Ezechiela." In Pismo Święte Starego $i$ Nowego Testamentu $w$ przektadzie z języków oryginalnych ze wstępami $i$ komentarzami. Edited by M. Petrer, M. Wolniewicz, Vol. 3, Poznan $1992^{3}$, pgs. 395-484 [Biblia Poznańska].

11. Homerski, J. "Wstęp do Księgi Ezechiela." In Pismo Święte Starego i Nowego Testamentu $w$ przekładzie z języków oryginalnych ze wstępami $i$ komentarzami. Edited by M. Petrer, M. Wolniewicz, Vol. 3, Poznan $1992^{3}$, pgs. 390-394 [Biblia Poznańska].

12. Jasiński, A. S. Księga Proroka Ezechiela. Ez 16-20, Vol. 5, Opole 2018.

13. "Księga Ezechiela." Translated by J. Drozd. In: Pismo Święte Starego $i$ Nowego Testamentu $w$ przekładzie z języków oryginalnych. Compiled by a team of biblical scholars at the request of the Benedictines at Tyniec. Edited by. A. Jankowski et al., $5^{\text {th }}$ Edition, Poznań 2014, pgs. 998-1044 [Biblia Tysiąclecia].

14. Langkammer, H. Stownik biblijny, Katowice 1989.

15. Rumianek, R. Księga Ezechiela. Ttumaczenie $i$ komentarz, Warsaw 2009.

16. Rumianek, R. Orędzie Księgi Ezechiela, Warsaw 1999.

17. Rumianek, R. "Problem odpowiedzialności według Ez 18,2," in Mitość jest z Boga. Wokót zagadnień biblijno-moralnych. Studium ofiarowane ks. prof. dr. hab. Janowi Łachowi, Warsaw 1997, pgs. 359-366.

18. Rumianek, R. Z rozważań nad Starym i Nowym Testamentem, Warsaw 2001. 
19. "Repentir," Dictionnaire encyclopédique du Judaïsme. Esquisse de l'histoire du peuple Juif. Calendrier. Edited by G. Wigoder. Compiled by S. A. Goldberg et al., Paris 1993, pgs. 960-963.

20. Rose, A. "Introductions aux lectures de l'année liturgique." In: Missel de la Semaine présenté par P. Jounel. Texte liturgique officiel, Paris 1973.

21. Strong, J. Hebrajsko-polski i aramejsko-polski stownik Stronga z lokalizacja stów hebrajskich $i$ aramejskich oraz kodami Baumgartnera (Prymasowska Seria Biblijna 45). Translated by A. Czwojdrak, Warsaw 2017.

22. Tidiman, B. Le livre d'Ezéchiel, Vol. 1, Vaux-sur-Seine 2007.

23. Wilson, R. "Ezekiel." In Harper's Bible Commentary. Edited by J. L. Mays, San Francisco 1988, pgs. 652-693.

24. Witaszek, G. Myśl społeczna proroków, Lublin 1998.

25. Weingreen, J. Hébreu Biblique. Méthode élémentaire. Nouvelle édition revue et corrigée. Translated by P. Hebert, J. Morgain, Paris 1984.

26. Zimmerli, W. Ezechiel (Biblischer Kommentar Altes Testament. Ezechiel 1-24, Vol. 13/1), Vluyn $1979^{2}$.

27. Zimmerli, W. "Le message du prophète Ezéchiel," Compiled, arranged, and translated by S. de Diétrich, Cahiers Bibliques 11(1972), pgs. 3-25.

28. P., Editor. "50 mots de la Bible," Cahiers Evangile 123(2003). 